\title{
Wanderlust without Wandering: Managing a Travel Blog during the COVID-19
}

\author{
Prazer de Viajar Interrompido: Desafios de um Blog de Viagem Durante a \\ COVID-19
}

"Traveling frees your soul, teaches you things that no classroom does. Traveling transforms you into the person you are but routine does not allow you to be," posted Maryana Teles on Instagram, on March 10, 2020. She was happy to have managed to fit a 6-day volunteer job in Cabo Frio, a beach city in the northern coast of Rio de Janeiro state, in Brazil, to show people that it was possible to live a volunteer experience for a short time.

Mary, as Maryana is also called, created the blog Vida Mochileira (Backpacker Life) to give tips on low cost trips and encourage women to travel alone. While in Cabo Frio, she created posts to publicize brands and business partners, provide information about volunteer programs, and display personal photos, in which she appears enjoying the places she visited. The traveler was following the news about coronavirus, but everything seemed very distant until she started receiving direct messages on Instagram: "Mary, is everything okay? It is all closing here. How come you are still going to the beach? Don't you think it's dangerous to go to the beach now?"

1. Universidade do Porto, Instituto de Sociologia, Porto, Portugal.

2. Universidade Federal do Rio de Janeiro, Instituto COPPEAD de Administração, Rio de Janeiro, RJ, Brazil.

3. University of Louisville, College of Business, Department of Entrepreneurship, Louisville, Kentucky, USA.

Cite as: Pinho, V. M. de, Monteiro, J., \& Binhote, J. (2021). Wanderlust without wandering: Managing a travel blog during the Covid-19. Revista de Administração Contemporânea, 25(spe), e200243. https://doi.org/10.1590/1982-7849rac2021200243.en
Suddenly, she realized that the situation was more serious than she had imagined. She was hearing about closing borders and restricting travel. "The only thing I could think of was the expedition I had organized for the month of April, when I would take twenty people to Atacama, in Chile, and Salar Uyuni, in Bolivia." Maryana called her travel partner and said: "Carla, I don't think it is going to happen. We will have to cancel the expedition."

On March 11, 2020, Maryana uploaded the first post warning about the danger of coronavirus and shared her doubts about being able to continue traveling (Figure A1). The blue sky of Farol beach, in Cabo Frio, watched from above the white and soft sand shrinking with each lick of the sea. Nature continued its cycle as a whirlwind of thoughts filled Mary's mind: "What do I, Maryana, as a travel influencer should communicate in times like this, when even the World Health Organization (WHO) is advising not to?" The entire Vida Mochileira business was at risk.

JEL Code: A2O, L83, N7

Editor-in-chief: Wesley Mendes-Da-Silva (Fundação Getulio Vargas, EAESP, Brazill) Associate Editor: Paula C. P. de S. Chimenti (Universidade Federal do Rio de Janeiro, COPPEAD, Brazil) Guest Editor: Leonardo Marques (Universidade Federal do Rio de Janeiro, COPPEAD, Brazil) (c) Reviewers: Olga Coutinho Pépece (Universidade Estadual de Maringá, Brazil) (C) Marcelo Guedes Carneiro (Escola Superior de Propaganda e Marketing - ESPM, Brazil) (C) Peer Review Report: The Peer Review Report is available at this external URL. Accepted: November 17, 2020 


\section{WHEN LIFE FALLS INTO PLACE}

Maryana Teles is from Rio de Janeiro and introduces herself on her blog as publicist, diver, photographer, content producer, blogger, waitress, and "any other profession that puts me closer to my dreams." She started working at an advertising agency at the age of 16, to help her father with the expenses and to "earn my own money and pay for my own things." The loss of her mother, still young, provoked a sense of urgency and enchantment for life:

My mother's death taught me, among other things, that if we have a dream and it is important, it needs to be lived now and we should not wait until after our retirement - which in my mother's case didn't even happen - and for many people too it will not arrive. Live intensely with the certainty that you can do things today. Nobody knows what awaits us tomorrow.

Mary likes to say that if you pursue your dreams "life will fall into place." So, the taste for travel was gradually built because of the internship opportunities she had during college. As an exchange student of Madeira University, in Portugal, she looked forward to the summer holidays to organize a 33-day backpack throughout Europe, traveling on a low budget and visiting as many countries as possible. Therefore, she started to research tips about what to do, what to take and realized that there were almost no travel blogs with information organized to help her planning.

At the time, I didn't know how to plan or to organize bags, so I researched everything on Google and instead of copying everything, I read a lot and tried to adapt to my reality, because what we read is not always appropriate for our lifestyle. So I always took care to adapt everything to my reality as a traveler.

As Mary organized and planned her vacation, she realized that more information was missing. In addition to having to resort from numerous sources to obtain the necessary information to plan the trip well, it would also be the first time she would travel alone and the closer to the day of departure the more nervous she became. A woman backpacking alone, across Europe, seemed a "bad idea" to her father and friends and nobody said: "you must go, it will be incredible." On the contrary, her grandmother "was going to die of worry. The only person who could encourage myself not to give up was me."

On my first backpacking, I slept on a shopping bench, became friends with the mall security guard who still talks to me on my Facebook, walked alone in the streets of Sevilla at 4 a.m. with everything dark, slept on the airport's floor because I didn't want to spend money with lodging. I walked a lot, made a lot of friends, laughed a lot, ended at the house of a French girl I met on the train from Munich to Paris, went into a party in Munich with strangers I bumped on the streets, asked for changing rooms when I saw people smoking weed in my hostel bunk, slept in a room with seven men and only I as a woman. I realized that I'm funny alone, got a hundred-euro fine in Vienna for not paying the subway ticket, I understood that my company is enough for me and many other things that made me who I am today.

The experience of backpacking alone transformed every time off or holiday of more than three days into a possibility to plan a next trip. Wanderlust ${ }^{1}$ was going to take Mary to many different parts of the world. "And so, my passion for traveling began.”

\section{VIDA MOCHILEIRA}

Maryana created Vida Mochileira blog in 2016, after spending 23 days between Bolivia, Chile, and Peru, to record her travel diaries and inspire others who wanted to travel more while spending less. She published roadmaps, shared her planning and expense control spreadsheet, gave tips on transportation, accommodation, taught ways to earn money while traveling, and clarified about volunteering and responsible tourism. The blog attracted business partners and began to monetize its content through the promotion and recommendation of services she used during her travels (Figure A2). Besides the blog and an Instagram profile, Vida Mochileira can be found on Facebook, Pinterest, and YouTube, where Mary uploads videos once a week. It was also in 2016, during another exchange trip, that she met her husband-to-be, Mark. Instead of staying just six months as planned, England became her new home country. During the first three years of existence of Vida Mochileira, Mary worked as a waitress to finance her trips. She produced videos and shared her experiences as a woman traveling alone through Thailand, Morocco, Spain, and Czech Republic, and volunteering in France, England, and Brazil. Since then, Mary has visited four continents, lived in four different countries, and financed her travels with money she earned from her different jobs.

Her content attracted sponsors and business partners that became important sources of income, generated from creating advertising for brands and companies on different social media platforms (Table A1). In 2019, Mary resigned from her job to dedicate herself exclusively to creating low budget travel content at Vida Mochileira. She establishes the value of each post according to the content created, since the posts are personalized and "each platform will require a type of energy to produce that content." 
Writing a blog post takes a lot more time than recording three stories on Instagram. And they will be gone in 24 hours. My blog post will stay there permanently. I must consider all of this. A video on YouTube continues to be watched by new subscribers to the channel while it is on the platform. I also must consider how long it will take me to record and edit a video. Will I need any props for the video? Anyway, it all counts. I try to get the brand's most detailed briefing.

Additionally to the income from advertising, Maryana receives commission in affiliate programs such as: purchase of courses for travelers and volunteer programs (Worldpackers Academy), travel insurance (Seguros Promo, Safetywing), accommodation (Booking.com; Airbnb), internet chips (Yes Brasil), currency exchange (Transferwise), car rental (Rentcars), attraction and queue booking (Get Your Ride, Civitatis), and tours and experiences (Fui Gostei Trips, Eco Desert Morocco, Brother's Trips, Hang Gliding in Rio).

Vida Mochileira was created as a space for Mary to share her learning as a lone traveler with all those who were looking for new experiences and friendships. It portrays her worldview and encourages women to travel alone. Mary made use of her blog and Instagram profile spaces to share her experiences as an immigrant, newlywed, to reveal and discuss the comments she received as direct messages and that dealt with topics about other women's insecurities in traveling alone, volunteering, fears, and hope. Through social media, Vida Mochileira attracted followers who identified themselves with not only a taste for adventure, but also with Maryana, in a closer and more personal relationship. Her digital business made it possible for her to interact with her followers and adapt the information according to their responses. She could explore a topic in abundance, as the amount of information was regulated by the engagement of her fans - all of this in a swift way, allowing her to keep up to date with pertinent subjects in Brazil and around the world as well as prepare, change, and spread her messages quickly. The mobile forms of communication in the palm of the hand, through smartphones or tablets, presented unique opportunities for Mary to increase the penetration of Vida Mochileira, being able to reach followers in the digital space and in real time, where and when they were, and influence in the decision of purchasing a course or product from her partners.

Topics to be addressed were often inspired from direct message on Instagram, which worked as a 'thermometer' for her (Figure A3): "I went to spend the Carnival in Rio de Janeiro and, right after posting the first photo, I started receiving messages: Mary, why are you enjoying Carnival alone? What does Mark think of that?" Surprised, Maryana thought how it was possible that so many limiting beliefs survived the second decade of the 21 st century. How could she help more women? On trips and day-to-day?

So, she had the idea of planning and embarking on a journey with a group of travelers to Bolivia and Chile. This would be a way to expand her sources of income: instead of only receiving commission for the recommendation of travel services, she would also earn with the accomplishment of the trip itself. That is why the expedition to Atacama and Salar de Uyuni in April 2020 was so important to her. It was a new product, where in addition to the tours, she would stimulate conversations among the travelers to help them overcome their fears of traveling alone, tipping on how to become digital nomads, and how to save on traveling, being practically an intensive mini course during the ten days they would spend together. Mary would be able to personally guide, support, and encourage other women to share among themselves their own journey of self-discovery. "The expedition is a new product, and it is a way to integrate the storytelling of my life and my personal experience with my business on social networks," Mary declared.

The Vida Mochileira community is composed of $70 \%$ women and $50 \%$ of them are between 25 and 40 years old. In July 2020, there were more than 57.000 followers on Instagram, 46.000 on Pinterest, and 14.000 subscribers on YouTube. But the pandemic put the entire business at risk.

\section{THE TRAVEL SECTOR AND THE IMPACT OF \#STAYHOME}

The COVID-19 disease started in late 2019 in China and rapidly spread throughout the entire world. On March 11, 2020, COVID-19 was declared pandemic. Many countries, in attempt to control the contamination among its citizens, imposed different measures to diminish the contamination of people, including curfews, requirements of social distancing, quarantines, self-isolation, and the most severe, lockdowns, with restrictions to circulation of people, temporary shutdown of non-essential businesses, and closing borders to foreign citizens.

This unforeseen crisis caused by COVID-19 triggered what has been called the most severe economic recession of the global economy, with forecasts of decrease in the global domestic product (GDP) of 5.2 percent and higher percentage in developing countries, due to impact on business activities in many sectors, harms on peoples' health and well-being, decrease of incomes, and increase of unemployment rate ${ }^{2}$. By April 20, the World Tourism Organization declared that $100 \%$ of the world had travel restrictions directly affecting its sector and travel-related industries. Prior to these constraints, according to the World Travel \& Tourism Council, tourism was one of the 
largest and growing sectors of global economy despite some shocks and crises, contributing around $10.3 \%$ for global GDP, generating one out of four new jobs created by the sector worldwide, boosting US $\$ 8.9$ trillion dollars, and transporting around 1.5 billion travelers internationally in 2019.

Despite facing a new crisis due to COVID-19, tourism is known to be one of the most resilient sectors of the world due to its capability to rapidly adapt to changes. For instance, the rise of low cost airlines companies (1970s), the advances of information and communication technologies along with the spread of internet (late 1990s), and mobile phones and the rapid digitalization of the world (starting in mid-2000s) triggered the sector to provide online products through what is called e-tourism. This movement was boosted by meta-search websites, like Google, along with new players in the sector such as online travel agencies and aggregators (e.g., Booking.com, Expedia), converting the business models from business to business (B2B) to business to consumers (B2C), and transforming the consumer behavior toward direct consumption of tourism with access to information in real time.

Additionally, peer-to-peer (P2P) collaboration and the sharing economy favored the interaction among users on virtual networks and platforms, promoting exchanges, creating bonds and trust among consumers/prosumers ${ }^{3}$, and strengthening their power on digital communities for reviews of commercial establishments (e.g., TripAdvisor; Yelp). Empowered prosumers used their own social media (e.g., Instagram, Facebook, Twitter, YouTube) to share their experiences and potentially influence future consumers ${ }^{4}$, reinforcing the value of electronic word of mouth (eWoM). The traditional B2B and B2C business models were changed once and for all.

This phenomenon has revolutionized the tourism sector, making changes on consumer behavior, and reshaped its marketplace. In 2018, Forbes reported the impact of Instagram in the decision of travel destinations of Millennials (born between 1981 and 1996) and Euromonitor International (in 2019) also highlighted the power of social media influencing consumers' travel plans through Instagram and YouTube. Nonetheless, the tourism ecosystem has been impacted with COVID-19 pandemic. If the restrictions of locomotion limited in-person interactions and traveling, on the other hand, consumers' behavior toward online and digital solutions increased even more amid the crisis.

Google report in May 2020 about consumers' interests during the pandemic shows a spike in the use of Google search website, leading to think how consumers adapted their routines to spend more time online, discovering new forms of connections to virtually nurture relationships and to practice more self-care. Social media posts also showed trends for some topics, while others were less cited.

Comscore digital agency issued a detailed report about Latin America social media publications (posts) and user actions (like, comment, share, and save) from March 2019 to March 2020 related to themes that interested users of Instagram, Facebook, and Twitter.

Facebook posts increased in the following categories: Government $(+35.76 \%)$, Publishing $(+35.23 \%)$, and Health $(+23.43 \%)$. Conversely, Telecommunications (-23.65\%), Influencers (-22.61\%), and Media and Entertainment $(-17.91 \%)$ were the categories that showed decrease on Facebook posts. Instagram presented an increase on posts about Government (+26.33\%), Finance $(+29.93 \%)$, Publishing $(+24.21 \%)$, and decreased posted content about Travel and Leisure (-34.15\%), Sports and Recreation $(-32.46 \%)$, and Technology (-21.14\%). According to Comscore, there was a massive drop of posts on Twitter on most themes, except for Government $(+8.76 \%)$ and Publishing $(+8.64 \%)$. Decrease on Consumer Goods posts $(-54.19 \%)$, Telecommunications $(-48.79 \%)$, and Automotive $(-44.55 \%)$ was significantly high on Twitter.

Considering the same period for 'actions,' i.e., social media users' behaviors related to sharing, liking, saving, or commenting on posts, Facebook showed an increase on Government (+61.55\%), Sports and Recreation (+65.11\%), and Finance $(+34.77 \%)$. Instagram actions increased on Finance (128.52\%), Health (109.19\%), and Education (54.97\%). Twitter actions augmented on Retail (84.88\%), Finance $(+77.49 \%)$, and Health $(+48.68 \%)$. On the other hand, Comscore indicated a decrease on actions on Facebook regarding Automotive $(-41.68 \%)$, Telecommunications $(-38.09 \%)$, and Influencers $(-31.85 \%)$. Instagram actions decreased on Sports and Recreation (-54.42\%) and Automotive (-18.96\%), and slightly affected Consumer Goods (-0.03\%). Twitter actions decreased on Automotive $(-67.56 \%)$, Telecommunications $(-44.40 \%)$, and Influencers $(-33.82 \%)$.

The access to social media platforms also increased during COVID-19. E-marketer estimated a spike of $40 \%$ of use of WhatsApp, Facebook, and Instagram by mid-March and doubled the use of lives on Instagram and Facebook in the same period. However, despite the growth of internet use amid COVID-19, several businesses sectors and industries were highly impacted by peoples' locomotion restrictions for example, touristic and travel-related activities running on both online and offline models, such as airline companies, car rentals, lodging, travel insurances, to mention a few. The pandemic put down the Euromonitor International forecast that by 2024 online sales would be responsible for more than $50 \%$ of the global travel industry, directly influencing consumption and e-WOM of digital content produced by 
social media influencers, whose followers would have to postpone their travel plans.

\section{THE TRAVEL INFLUENCER}

As a new occupation raised on the internet era, digital media influencers of several industries could also face a decrease in their income due to the impact of COVID-19 pandemic, putting at risk a multibillion-dollar worldwide revenue from influencer marketing, forecasted to reach $\$ 15$ billion by $2022^{5}$. The digital influencer is a person with a famous profile on social media who gained credibility in a specific sector. With thousands and sometimes millions of followers on digital platforms, this person can set trends and behaviors monetizing this influence, making personal income and revenues.

Maintaining the travel sector, there is a variety of digital influencers on the internet, depending on the product/ service, purpose, and budget. Generally, digital travel influencers offer tips for travels according to their personal choices and/or partnerships, such as accommodation, airline search, car rental, currency exchange, internet chips, local attractions, and ways of booking lodging and other services ahead through websites. These differences will depend on each profile focus because travel-related digital influencers have a wide scope that may encompass travel in general, luxury travel, low budget, volunteering while traveling, travel with kids, and an even more niched segment of traveling linked to photography.

Vida Mochileira offers a free e-book with tips for traveling on a low budget, shares Mary's own experiences while traveling alone on the blog, on the Instagram profile, and on a weekly podcast series called Se Meu Mochiläo Falasse (in English: If Only my Backpack could Talk) in partnership with Andrea Leonel. In addition, Mary Teles unveils her own reflections about her self-knowledge process, engaging in social projects and self-reflection contents, especially regarding being a woman, backpacking alone, and other contents related to self-knowledge during volunteering experiences.

Many digital travel influencers explore the journey tip planning, recommendations of accommodation, local attractions, lowbudget travel tips, and volunteering experiences, and engage in paid partnerships with travel related companies. Some develop additional activities such as @fuigosteicontei, which participates in @redescobrindonossobrasil (rediscovering our Brazil), a voluntary crowdfunding project to encourage national tourism, through the creation of an e-book travel guide, in which bloggers, journalists, companies, and freelance professionals collaborate.

The profile @intercambiovoluntario (volunteer exchange) offers tips and a free e-book explaining, in four steps, what is it and how to be accepted as a volunteer, and mentors those who are willing to participate in an exchange program. Another way of exploring the travel segment is the offer of guidance for those traveling with children. The @lalarebelo provides tips for destinations such as Disney parks in the United States and unusual places like the United Arab Emirates, in addition to providing customized itineraries.

For the travel sub-segment in general, Luisa from @janelasabertas (open windows) provides tips and discounts on accommodations and travel insurance. She produces exclusive and free content for those who subscribe to the Janelas Abertas blog newsletter, who also receive an e-book with a complete guide on how to travel alone as a gift. Additionally, Luisa offers online course for those who want to learn how to grow and monetize travel blogs through the WorldPackers website, and Thais, another travel blogger, from @thaistowersey, shares not only travel tips and discounts to her followers, but also the option of traveling with her to Jalapão in Tocantins at the end of 2020. The @blogumviajante (a traveler) goes beyond the travel tips and sells handmade postcards from Atacama. Similarly, @prefiroviajar (I prefer to travel) sells travel text-message T-shirts.

For those who like to travel and photography, @maladeaventuras (adventure luggage) is managed by two photographers who offer presets (pre-defined filters to edit photos on Adobe Lightroom software) that improve the quality of photos, as well as discounts for lodging, volunteering, and obtaining visas. They also offer several products related to travel such as planner, cork world map, and e-books, specializing in photography and Canva, a digital design platform for creating graphic materials.

The @mundosemmuros (world without walls) targets those who want to improve their photography skills offering courses, presets, and LUTs (personalized techniques to edit or color correct images) options for their followers. For those who like traveling, photos, yoga, and a little bit of everything, Anna Laura (@anna.laura) is a journalist who shares travel tips and offers advice on how to use Instagram and photo editing workshops when attendants can buy presets to improve their photos. Her Instagram profile addresses self-awareness issues and reports on experiences such as retreat in India, yoga, and astrology, and offers information on purchasing products, as well as discounts from travel-related partners.

In a broader way, Table $\mathrm{A} 2$ in the Appendix presents additional information about different products and services provided by selected digital influencers known for their travelrelated contents.

The main forms of monetization of digital influencers are through the YouTube platform, sponsored posts, partnerships with companies, and the sale of products or services offered by the influencer her/himself. Each of these 
forms works differently and has its own monetization logic. Usually, YouTube is the champion for income. Monetization on the platform is impacted by several factors, such as number of followers, number of clicks on ads shown in the videos, and ad format.

Another form to make money with social media platforms is sponsored posts. In this modality, the digital influencer is hired by a company/brand and can reach an agreement about different forms of ad, from a post to a video about the product/service, from small comments or quotes to a clear exhibition of the brand in the posts, conventional videos, or short and temporary videos (stories on Instagram, for example). These are sponsored posts that many influencers display on their profiles as advertisements.

Additionally, partnerships with companies also generate posts that advertise a company's products on social networks. Unlike sponsored posts, in this case the digital influencer receives a commission for the sale of each product that happens through his/her recommendation. Likewise, selling products or services is also a widely used form of monetization on social media - for instance, in-person or online courses, travel packages, all types of products, and others.

All forms of online monetization, however, depend directly and/or indirectly on the content offered by the digital influencer. The relevance of the content produced and the identification of followers with the posts is what potentialize the generation of revenue. Regardless of the source of the revenue (YouTube, sponsored posts, percentage of the sale of advertised products, or direct sale of products), all forms of monetization depend on the relevance of the digital influencer, that is revealed by the identification of the audience with the content produced. The reach and the engagement with the content produced are measurements that turn a digital influencer profile attractive to brands and business partners.

However, despite the rise of consumption through internet amid COVID-19 crisis, Nielsen indicates that buying and selling digital ads in a global pandemic is challenging, especially for sectors highly affected by countries' measures to diminish the contamination rate of their citizens, for instance, the tourism sector and its travel-related industries.

\section{THE FUTURE AHEAD VIDA MOCHILEIRA}

"Postponing the expedition was a wise decision. I don't even know if it will still be possible to travel in 2020," thinks Maryana while seated on the bench of her 'private park,' at the end of the street where she lives, in England. She had managed to get home on the last flight out of Brazil before the lockdown. The pandemic caused by COVID-19 directly affected her business and everything she had planned seemed infeasible. The owner of one of the companies she had a commercial partnership with called her to propose: "let's offer a 40\% discount to your followers." Surprised, Mary reacted: "What do you mean? I can't position myself as a company that is encouraging traveling right now."

In May 2020, Vida Mochileira's revenue had decreased seven times and there was no forecast on when it would be possible to travel again. Maryana decided to dedicate herself to organize the homepage and update the contents of her blog, invest more on her Pinterest and Facebook fan pages, and take online courses to improve the production of her contents. She was taking advantage of the long period at home to study on topics of personal development, such as holistic therapies, meditation, yoga, astrology.

However, she kept thinking to herself about how to maintain her followers engaged until all this crisis was over, since the content she created was about travel itineraries and tips on tourist destinations. Mary also knew by experience that followers would react differently to sensitive topics, such as the post she uploaded during Carnival in Rio, when she had only a patch covering her nipples, and it cost her the loss of followers (Figure A4). Her biggest challenge was to stay on track. "It is extremely difficult to live on commissioning. There comes a time when you are confronted with opportunities that may tempt you to give it all up." Mary needed to find a way to continue with Vida Mochileira. And it had to be quick.

\section{NOTES}

1. Wanderlust (n.d.) is lust (or 'desire') for wandering. The word comes from German, in which wandern means 'to wander' and lust means 'desire.' In Merriam-Webster's dictionary. https://www.merriam-webster.com/dictionary/wanderlust

2. OECD Economic Outlook. Retrieved from https://www. oecd.org/economic-outlook/june-2020/ in July 03, 2020.

3. Expression coined by Alvin Toffler to refer to consumer as also a producer. This concept has been evolving further with the engagement of individuals on social media in different industries.

4. Retrieved from http://documents.worldbank.org/curated/ en/161471537537641836/Tourism-and-the-SharingEconomy-Policy-Potential-of-Sustainable-Peer-to-PeerAccommodation in June 26, 2020.

5. Retrieved from https://www.bloomberg.com/news/ articles/2020-04-01/how-social-media-influencers-areaffected-by-coronavirus-shutdown in February 07, 2020. 


\section{APPENDIX A}

Table A1. Financial sources of Vida Mochileira before COVID-19 pandemic.

\begin{tabular}{cccc}
\hline Source & Type of income & Main platform & Participation in total revenue \\
\hline $\begin{array}{c}\text { Advertising of products/services; } \\
\text { Affiliated partnerships: }\end{array}$ & Negotiation per contract & Instagram and blog & $5 \%$ \\
Volunteer program & Commission & Instagram and blog & Blog \\
Travel insurance & Commission & Blog & $10 \%$ \\
Accommodation & Commission & Instagram and blog & $10 \%$ \\
Tours and experiences & Commission & Blog & $30 \%$ \\
Expedition & Package per traveler & Blog & $0 \%$ \\
E-book* & Free for download & Instagram and blog & $0 \%$ \\
Online Course* & Commission & & $100 \%$ \\
Total ${ }^{1}$ & & & \\
\hline
\end{tabular}

Note. ${ }^{*}$ Online course was a direct source of revenue but was sold to Worldpackers Academy. E-book is free for download on https://vidamochileira.com.br (retrieved in June 07,2020$)$. ${ }^{1}$ Total does not include other affiliated partnerships such as internet chips, currency exchange, car rental, and attractions since they represent less than $1 \%$ of total revenue. Source: Information provided by the digital entrepreneur on June 07, 2020 and organized by the authors.

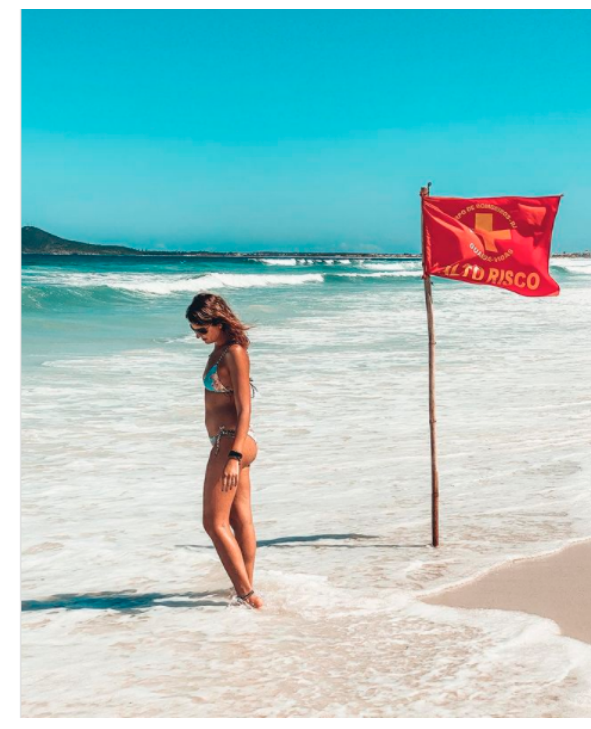

(D) vidamochileira $\cdot$ Seguir
Praia Das Dunas (Cabo Frio) vidamochileira Coronavirus: Cancelar ou não as viagens?

Oo que É? O coronavirus é uma familia de vírus que causam infecções respiratórias. SINTOMAS Tosse - Falta de ar/dificuldade para respirar - Diarréia - Febre $\cdot$ Problema gástricos • Pneumonia • Insuficiência renal

GRUPO DE RISCO

Pessoas com doenças graves ou crônicas, imunodeficientes, idosos grávidas.

COMO PREVENIR?

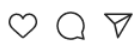

$\nabla$

1.418 curtidas

11 DE MARÇO

Entrar para curtir ou comentar.

Figure A1. First Instagram post referring to COVID-19.

Summary of the message on the post: what is coronavirus, symptoms, risk groups, how to prevent it. Source: Retrieved by authors from Vida Mochileira Instagram account (@vidamochileira) on May 07, 2020.

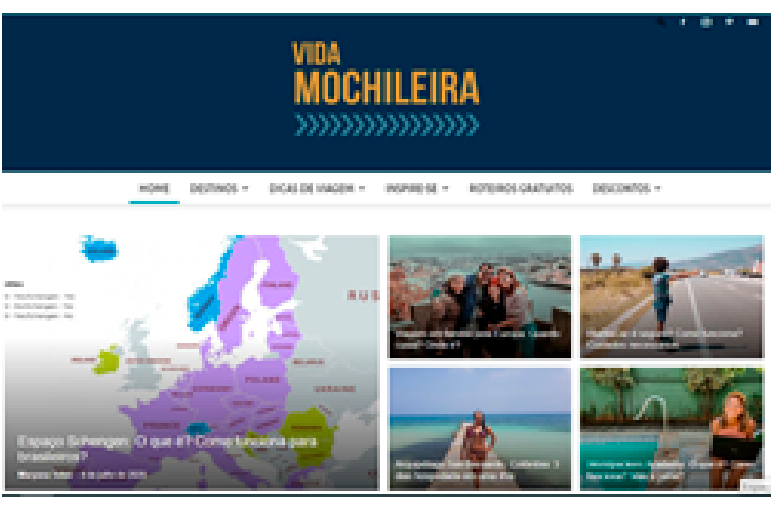

Figure A2. Homepage of Vida Mochileira blog.

Content of Vida Mochileira blog thumbnails: links to information about what is Schengen space and how it works for Brazilians; costs and where to go on a family trip around Europe; safety and precautions on the use of BlaBlaCar; tips on how to enjoy three days in San Bernardo archipelago, Colombia; what is Worldpackers, how it works and the value of it. Source: Retrieved by authors from Vida Mochileira blog (https://vidamochileira.com.br) on July 13, 2020. 


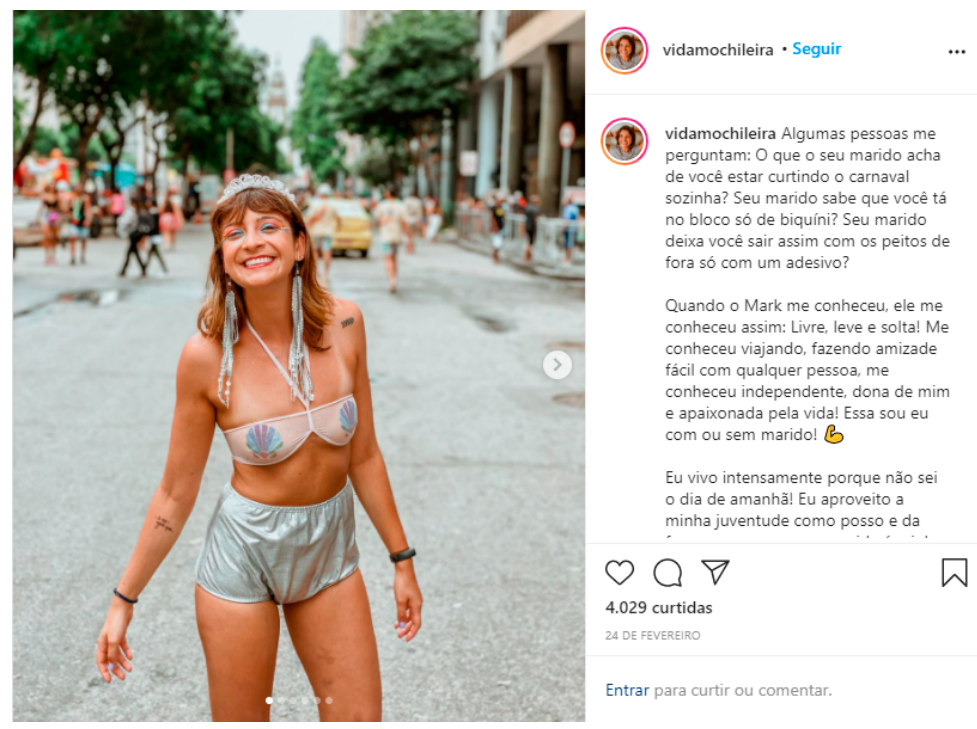

Figure A3. Post about Mary Teles enjoying Carnival without her husband.

Extract from the post: "Some people ask me: What does your husband think about you enjoying the Carnival alone? Does your husband know you're wearing only a bikini? Does your husband let you go out like that with your breasts sticking out just with a patch? When Mark met me, he knew me like this: Free, light, and loose! He met me traveling, making friends easily with anyone, he met me independent, owner of my own self and passionate about life! That's me with or without a husband!"

Source: Retrieved by authors from Vida Mochileira Instagram account (@vidamochileira) on July 11, 2020.
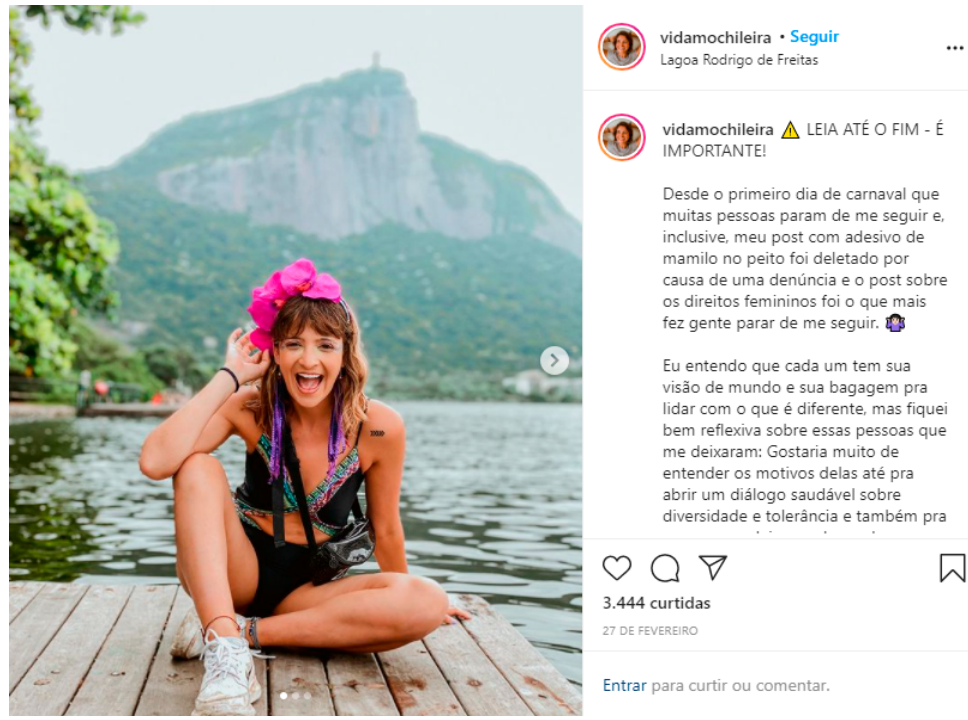

Figure A4. Post standing up to women's rights even though losing followers. Extract from the post: "Since the first day of Carnival a lot of people unfollowed me, and not only that, my post with a sticker on my nipple was deleted because of a complaint and the post about women's rights was the one that made even more people stop following me. I understand that everyone has its own world view and baggage to deal with the difference, but I got very thoughtful about those people that left me: I really would like to know their motives to open a healthy dialogue about diversity and tolerance and also to put myself always in a position of learning!"

Source: Retrieved by authors from Vida Mochileira Instagram account (@vidamochileira) on July $07,2020$. 
Table A2. Products and services offered by travel-related influencers on Instagram.

\begin{tabular}{cl}
\hline Products/Services & \multicolumn{1}{c}{ Instagram account } \\
\hline Personalized consultancy & @anna.laura; @mundosemmuros \\
Preset*LUT ${ }^{* *}$ & @maladeaventuras; @mundosemmuros; @anna.laura \\
Personalized itinerary & @lalarebelo \\
Expeditions & @thaistowersey \\
Online selling of travel-related items & @blogumviajante; @maladeaventuras; @prefiroviajar; @anna.laura \\
Workshop/Courses & @mundosemmuros; @janelasabertas; @anna.laura \\
E-books (free or paid) & @intercambiovoluntario; @maladeaventuras; @mundosemmuros; \\
Mentoring classes & @fuigosteicontei; @prefiroviajar; @janelasabertas \\
\hline $\begin{array}{c}\text { Trip planning, recommendations of accommodation, local attractions, paid } \\
\text { partnerships with travel related companies }\end{array}$ & @intercambiovoluntario \\
\hline
\end{tabular}

Note. ${ }^{*}$ Presets — personalized techniques to edit photos using Adobe Lightroom, software developed by Adobe Systems. ${ }^{* *}$ LUTs — personalized techniques for editing or color correcting on images. Source: Information collected on Instagram on July 10, 2020 and organized by the authors. 


\section{ABSTRACT}

This teaching case describes how Mary Teles, a digital entrepreneur and creator of Vida Mochileira travel blog, faced the crisis caused by COVID-19 in 2020 and how the preventive measures of closing borders and restricting locomotion and traveling during the pandemic represented a challenge to the continuity of a business that produces content for travelers. This real case was developed with primary and secondary sources of information and is recommended for application at Marketing, Services Marketing, and Digital Marketing disciplines in undergraduate or postgraduate courses of Business Administration and Hospitality and Tourism, allowing the discussion of the theoretical concept of positioning in the context of social media, in the tourism sector.

Keywords: digital entrepreneur; social media; tourism sector; brand positioning; teaching case.

\section{Teaching objectives}

This case was developed to be used in the session dedicated to brand positioning, in the Marketing, Services Marketing, or Digital Marketing disciplines, in undergraduate or postgraduate courses of Business Administration and Hospitality and Tourism, with data from a real digital entrepreneur (Maryana Teles, creator of Vida Mochileira blog) focused on travel-related contents and that was affected by COVID-19 crisis.

It is suggested that the instructor has already approached market selection, segmentation, and targetaudience in previous sessions and follows up with marketing mix decisions in subsequent sessions. The fundamental dilemma of this case calls into question rethinking the entire business and addresses the strategic decision to (re)position the Vida Mochileira brand. Marketing mix decisions will therefore be a consequence of the change in positioning and may be discussed in subsequent sessions.

At the end of the case discussion, students are expected to understand through inductive learning that brand positioning is a strategic decision for any business to succeed and conclude that positioning is: (a) key to brand differentiation and influences consumers' perceptions and purchase decisions; (b) a mindful choice of possible alternatives of the associations that a business wants to create in consumers' minds; (c) a follower-creator ongoing process of co-creating meaningful and relatable offers in online business. It is expected that students come to the conclusion that a digital business differs from a traditional business mainly because it is built 'in real time,' adapting to market changes in an agile way and debating issues relevant to people's lives.

\section{RESUMO}

O caso descreve como Mary Teles, empreendedora digital e criadora do blog de viagem Vida Mochileira, enfrentou a crise causada pelo COVID-19 em 2020 e como as medidas preventivas de fechamento de fronteiras e restrição de locomoção e viagens durante a pandemia representaram um desafio para a continuidade de um negócio que produz conteúdos para viajantes. Este caso real foi desenvolvido com fontes primárias e secundárias e é recomendado para disciplinas de Marketing, Marketing de Serviços e Marketing Digital em cursos de graduação ou pós-graduação em Administração e Hotelaria e Turismo, e possibilita a discussáo do conceito teórico de posicionamento no contexto das mídias sociais, no setor de turismo.

Palavras-chave: empreendedorismo digital; redes sociais; turismo; posicionamento de marca; caso para ensino.

\section{Protagonist and data source}

This teaching case was prepared based on primary and secondary data of the real digital entrepreneur, Maryana Teles, as protagonist and creator of Vida Mochileira. Primary data was collected by a recorded semi-structured interview with the founder of the company and responsible for all the contents developed on social media, mostly blog, Instagram, Facebook, and YouTube. Secondary data was retrieved from Vida Mochileira profiles on digital platforms, public websites, and official reports about the global tourism sector and social media platforms' policies and requirements to qualify to monetize published content. All data was organized and adapted to compose the teaching purposes of this case.

\section{Teaching plan}

The case was designed in order to allow the inductive learning about brand positioning. Therefore, no previous reading is required. However, if the instructor prefers, it is recommended the previous reading of the chapter "Crafting the Brand Positioning" by Kotler and Keller (2016) and/or the Harvard Business Review article "Branding in the Age of Social Media" (Holt, 2016) about how internet turned once-isolated consumers into influential communities that react to brand content and co-create brand positioning.

The case was developed for a lesson of 80 to 120 minutes, with the assumption that students will previously prepare themselves individually by reading and analyzing the case. The instructor can use the following assignment questions $(A Q)$ to guide the individual preparation of the students and to help focus their analysis of the case. These 
AQs were developed for the students' prior preparation. The instructor can choose to distribute them together with the body of the case, for individual preparation; or at the beginning of the class, to be discussed in small groups; or choose not to use them. In any case, the AQs are not intended to be used during the plenary discussion. To this end, discussion and transition questions serve this purpose and will be detailed later.

\section{Assignment questions}

1. What were the immediate impacts caused by the COVID-19 pandemic on the tourism sector?

2. As a digital entrepreneur in the tourism sector, what were the advantages and disadvantages of Vida Mochileira to deal with the challenges triggered by COVID-19?

According to the time available for the debate of the teaching case, the instructor could give 30 to 45 minutes for debate in small groups (e.g., from four to six students) before beginning the session. Alternatively, the assignment questions may be distributed only at this moment to guide the discussion within these groups. Therefore, the suggestion of time allocation for the session is in Table 1.

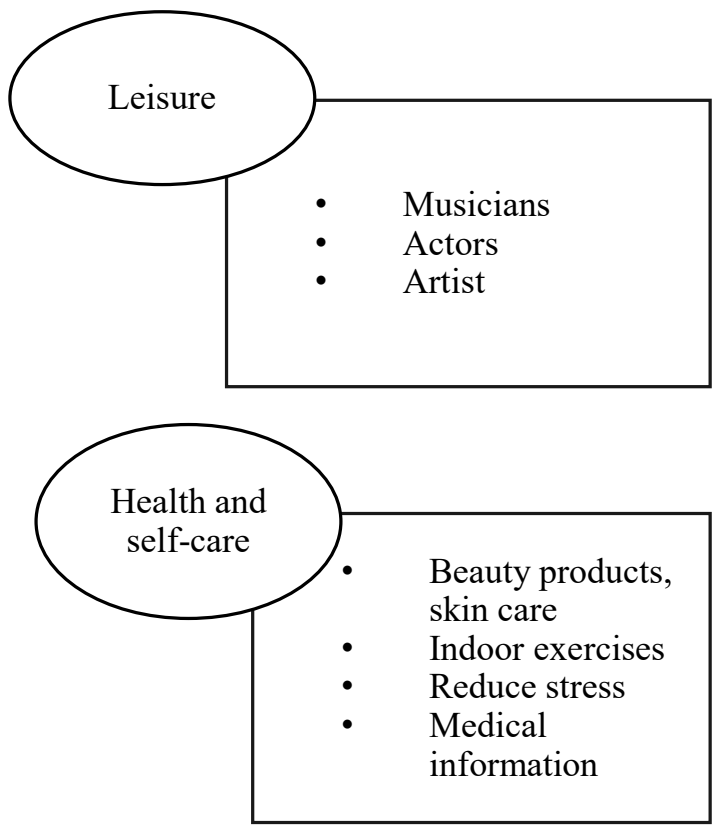

Figure 1. Expected responses for discussion opening.
Table 1. Suggested time allocation for session.

\begin{tabular}{ll}
\hline \multicolumn{1}{c}{ Activity } & \multicolumn{1}{c}{ Time } \\
\hline Debate in small groups & $30-45$ minutes \\
Opening & $10-15$ minutes \\
Discussion questions & $30-45$ minutes \\
Closure & $10-15$ minutes \\
\hline
\end{tabular}

\section{Case discussion opening}

The discussion opening must lead students to notice a change in their consumption of contents on their social media during the COVID-19 crisis, specifically about new profiles they started to follow.

It is suggested that the instructor encourage the debate starting from the following questions: Who did you start to follow during the quarantine? What kind of lives did you watch during this period?

Students are expected to highlight different changes brought by the pandemic and it is suggested that the instructor categorizes them (e.g.: leisure, personal development, health and self-care, cooking and house care). It is expected responses such as: musicians, reduce stress, indoor exercise, and selfknowledge content, as illustrated below.

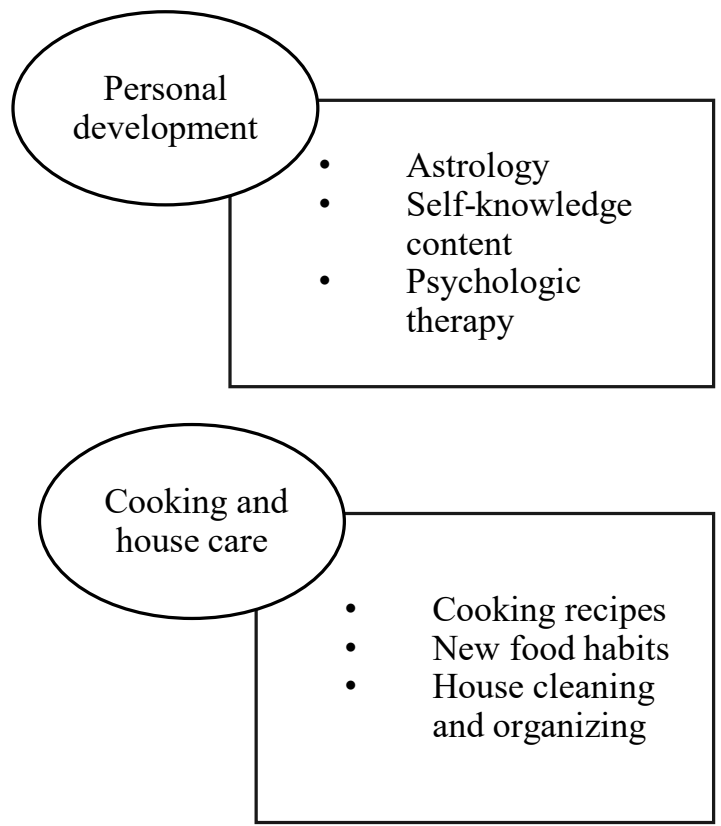


After acknowledging a change in social media consumption, the instructor will be able to initiate the debate, with questions related to the focus of this case - the impact of COVID-19 on the positioning strategy of Vida Mochileira.

\section{Discussion questions}

The following discussion questions (DQ) represent the main points that will assist the instructor to structure the discussion of the case. They are proposed to allow the inductive learning of marketing efforts to positioning a business:

1. What products does Vida Mochileira offer to its followers?

2. Who is the target audience of Vida Mochileira?

3. What is/are the differential/s of Vida Mochileira?

4. What is Vida Mochileira's reason to believe?

During the case analysis below, some transition questions (TQ) are suggested to be posed by the instructor in the session to move from one main point to the next one, helping smooth the flow and ensure progression.

\section{Case analysis with literature support}

The positioning session should follow the classic teaching sequence of segmentation, targeting, positioning (STP), once the creation of the positioning of a brand or company presupposes previous selection of the market segment and target audience, whose needs and desires the company intends to fulfill.

Positioning transcends the dimension of the company's product or service because it is based on the symbolic construction of differentiation perception and influences the purchase decision. According to Ries and Trout (2000), the positioning is not about the product, but the representation of a brand in the consumer's mind. It is what differentiates one brand from all others, even if their functional benefits are comparable.

Hence, positioning a company's offer means answering the question "who-sells-what-towhom?” (Rocha, Ferreira, \& Silva, 2012, p. 194). Based on this reflection, the educator can stimulate students to inductively identify the main elements of positioning: What is the company offering? Who is it for? What is its differential? What are the evidences that the company delivers its promises? Thus, the first discussion question of the case will help students identify Vida Mochileira products and their respective benefits.

\section{DQ1 - What is the portfolio of Vida Mochileira?}

It is important that the teacher emphasizes that positioning is a direction, a search for a constant balance of what the brand is and what it could be in the future (Kotler \& Keller, 2016). Establishing a brand positioning means making it clear to what business category the offer belongs, opening a horizon of possibilities of product offers. On the other hand, the offers of a digital brand can be both tangible and intangible, since interactions mediated by social networks show significant differences in relation to traditional brands. Douglas Holt (2016) points out that social networks significantly change the way people relate to brands, whether these brands are products, services, or people, who advertise and offer content to an audience of followers. People have no interest in the content of brands. People want to discuss issues relevant to their lives. Social networks allow people to share common interests, establish connections, and exchange experiences, even if they are geographically distant. The author emphasizes that people have lost interest in traditional brands because their focus is on creative excellence and charming stories, while digital brands present everyday stories and prioritize the creation of relevant content. Social networks amplified the practices and ideologies of what Holt called "crowdculture," (Holt, 2016, p. 42) referring to the subcultures that promote cultural innovations in social networks through: (a) intense interactions, collaborations, and exchanges of ideas between content creators; (b) obtaining data in a fast way and almost instantaneous updating/alteration according to reception or criticism of the content produced, called "cultural prototyping" (Holt, 2016, p. 43); (c) low production costs; (d) world fame in record time; (e) direct fan interaction with content creators; (f) improvisation, vulnerability, personal themes.

The question about Vida Mochileira's portfolio provides this vision of present reality and a look into the future: considers the current tangible offer and invites to think about a possible portfolio to become more competitive, more unique. Thus, Vida Mochileira’s products can be renewed and expanded according to the changes in the market scenarios where the company operates. The following transition question is suggested to stimulate students' contributions:

TQ - What does Mary Teles offer to her followers? What is the portfolio of Vida Mochileira?

Based on the available data on the case, students should be able to understand that product and service offers 
derive from the personal travel experiences of Mary Teles, who curates information about places to go and posts on Vida Mochileira's social media platforms, along with advertising of brands and partnerships with trusted companies.

Thus, it is expected responses such as: travel itineraries, tips for planning, accommodation and low-cost tours, volunteering, discount on products and services from travel partners, expeditions with customized travel experience with her, and online course on how to make money with an Instagram travel profile. It is suggested that the instructor registers the students' answers on the board as illustrated on Sheet 1 of the chart (Appendix B, Figure B1).

\section{TQ - What does Mary Teles offer to Vida Mochileira followers beyond its portfolio?}

This question aims to stimulate students to be able to list intangible attributes Mary offers to her followers, such as encouragement and confidence to travel alone, selfknowledge, worldview based on freedom, and discussion about women in society and female empowerment. Therefore, it will be possible for them to acknowledge that Mary Teles not only shares her personal travel experiences, but also her own opinions on topics she considers relevant. The instructor should register all the answers to the transition questions on the chart (Figure B1), clustering them as those affected and those not affected by COVID-19 pandemic (Appendix B).

\section{DQ2 - Who is the target audience of Vida Mochileira?}

Kotler and Keller (2016) argue that the classic selection of targeted audience follows the criterion of grouping people with similar characteristics, such as geographic, demographic, and/or their level of education. However, these types of descriptive segmentation provide limited information about interests, needs, and/or desires of a person, unveiled by psychographic segmentation. The teacher may motivate the observation that Vida Mochileira combines demographic (women, between 25-40 years old) with psychographic elements (e.g., encouragement to travel alone). In this way, it might be possible to address the behavioral dimension of the consumption decision, experienced by a certain group of consumers who choose to travel alone and, possibly, resemble the needs they wish to fulfill and the expected benefits of this lifestyle (Kotler \& Keller, 2016).

The following transition question may help the instructor define the Vida Mochileira's target audience and their knowledge, attitude, use, or reaction to offers for this lifestyle.

\section{$\mathrm{TQ}$ - Who is the main public of Vida Mochileira?}

Based on data available on the case, it is expected that the students highlight that the majority of the public are women $(70 \%)$ between $25-40$ years old (50\%), who understand Portuguese and are spread across all the digital platforms of Vida Mochileira, most of them being on Instagram. The instructor can categorize the answers by types of segmentation previously mentioned, namely geographic and demographic (Figure 2).

\section{GEOGRAPHIC AND DEMOGRAPHIC SEGMENTATION}

Majority - Women (70\%)

Age range between 25-40 years old (50\%)

Understands Portuguese

Spread across all VM social media, mainly IG

Figure 2. Types of segmentation.

\section{TQ - What kind of people relate to Vida Mochileira?}

The educator may stimulate the students to reflect about elements of the personality and lifestyle of Mary that could influence the predominance of women following her on social media. According to the storytelling of her own life and experiences displayed in the case, it is expected that students can identify her sense of freedom and courage to travel alone since tender age, always in search of self-development. The students may also notice there is a prevalence of content about women empowerment and encouragement for them to travel solo, seek self-knowledge and personal development. According to the students' answers, the instructor may categorize the responses in the psychographic segmentation, according to Figure 3.

\section{PSYCHOGRAPHIC SEGMENTATION}

Sense of freedom and courage to travel

Always searched to improve herself along the years

Working fully to develop content about women

Empowering and encouraging them to travel alone

Seek self-knowledge and personal development

Figure 3. Types of segmentation. 
Prior to continuing discussing the case, the teacher may highlight the importance of choosing a proper segmentation criterion to understand the motivations and drivers of a target group, create a relatable offer to consumers, and become their brand of choice.

\section{DQ3 - What is different about Vida Mochileira?}

A company's offer encompasses functional aspects and unique benefits provided to consumers, making it possible to identify similarities and differences among brands and make a choice. Kotler and Keller (2016) suggest that to build the differential of a brand, managers must: (a) determine a competitive structure of reference; (b) Identify the ideal associations with the brand regarding points of parity and differentiation compared to selected competitors.

In addition, Kotler and Keller (2016) state that the definition of the competitive structure begins by choosing the target market, where the company can identify the players against which it competes for a specific target audience. Once the competitors are defined, it is possible to proceed to identify the points of difference and of parity and define the associations the company wants to create on consumers' minds.

According to Keller, Sternthal, and Tybout (2002), the points of difference are the attributes or benefits that consumers believe to be exclusively offered by a certain brand and cannot be compared to other competitors' offers. Conversely, points of parity refer to the similarities shared and offered by different brands and can be used by the manager as an opportunity to evaluate its competitive situation (Brunner \& Wänke, 2006).

The result of this exercise should serve to identify and select the main differentials of the Vida Mochileira brand. The following transition questions may assist the instructor to select the competition and fill out the table of points of parity and difference.

\section{$\mathrm{TQ}$ - What are the similarities between Vida Mochileira and other travel profiles? And what is unique to it compared to other travel profiles?}

Considering the context of the case — during the COVID-19 pandemic, when restrictions to mobility and physical interaction imposed by countries, such as quarantine and borders lockdown, made travel impossible -, the world was going through a moment of economic uncertainty that caused a decrease in revenues especially in the tourism sector, impacting Vida Mochileira and other digital travel entrepreneurs.

Students should refer to the information available on the case and in Table A2 to answer the question, where they will be able to identify which Vida Mochileira offers compare and which differ from competition. It is suggested that the instructor build a table to note the common attributes and differences between Vida Mochileira and other profiles of travel influencers cited by students, as suggested below (Table 2).

Table 2. Points of parity and difference.

\begin{tabular}{|c|c|}
\hline $\begin{array}{l}\text { POINTS OF PARITY } \\
\text { (Similar offers) }\end{array}$ & $\begin{array}{l}\text { POINTS OF DIFFERENCE } \\
\text { (What is unique) }\end{array}$ \\
\hline Travel tips based on their own travel experiences and/or partnerships ads & Produces content to encourage women to travel alone \\
\hline Travel itineraries & Debates gender role \\
\hline Tips for financial planning of low budget trips & Encourages women's independence \\
\hline $\begin{array}{l}\text { Discounts for travelers (accommodation, airline search, car rental, curren- } \\
\text { cy exchange, internet chips, local attractions) }\end{array}$ & Weekly podcast series \\
\hline Use of IG posts and stories to share more travel content to followers & Engages in self-knowledge contents \\
\hline Use of other digital platforms (besides IG) for more travel content tips & Shares her own reflections about being a traveling alone woman \\
\hline Free e-book & Experiences volunteering as a social project \\
\hline
\end{tabular}

In the case the students focus only on the points of difference of other travel digital influencers, such as personalized consultancy/itinerary, workshops/courses, and travel related products, we suggest that the instructor writes on the board the answers and reinforces the question about what is unique about Vida Mochileira. It may happen that students are thinking of a traditional offline approach for product, therefore the instructor may draw their attention to what is different about the content of the posts Maryana creates so that they can conclude the core of Vida Mochileira is women 
empowerment. "The positioning decision is often the crucial strategic decision for a company or brand because the position can be central to customers perception and choice decisions" (Aaker \& Shansby, 1982, p. 56). To help students find elements of differentiation of Vida Mochileira, the instructor may use the following transition question:

\section{TQ - What attracts people to follow Mary? What kind of content does she create?}

The teacher shall mention Figures A3 and A4, as examples of posts from Vida Mochileira that can help students find elements to answer the TQ. The following contributions may be offered: Mary seems to be a free person, well resolved in relation to her body, addresses issues about women's autonomy and freedom, encourages women to value themselves more, and talks about relationships and respect for individuality.

Some students may bring to the discussion that many followers unfollowed Vida Mochileira because of this type of content. If so, the instructor may emphasize that a point of differentiation will result in inclusion of some and exclusion of others, attracting those who relate to the ideas the brand stands for. It is also important to recall that the logic of online monetization relies mainly on the identification and engagement of the public with the content offered, not necessarily on tangible products, as stated in the section "The travel influencer".

\section{DQ4 - What is Vida Mochileira's reason to} believe? What are the evidences that the company delivers its promises?

The fourth element of the positioning statement refers to what the company offers as guarantee that it will deliver to customers the promises identified as points of parity and as points of differentiation. The reason to believe is the evidence that ensures to the consumer that the brand will fulfill its promise. It is important to notice that the evidence or reason to believe in the approach of positioning businesses on digital platforms may play a double role once the content created, in some cases, is both the offer to be consumed and the reason to believe. Hence, sometimes the 'promise' (parity or differentiation from other offers) will be associated with a 'proof' (content) to fulfill consumers' needs and desires. The following TQs may help the instructor to invite the students to think that Vida Mochileira's reasons to believe can be evidenced by 'tangible' products as well as the 'intangible' aspects of Maryana's personal beliefs and purpose in life.

\section{TQ - How Mary ensures that her content remains relevant to her followers?}

It is expected that the students realize that posts, lives, stories, and videos are evidence of the benefits offered by Vida Mochileira as well as the frequency and diversity of topics published through posts on blog and Instagram and videos on YouTube. In addition, the partnerships to offer discounts to followers are also evidences of benefits promised by Vida Mochileira. The instructor should return to the table of points of parities and differentiations, elaborated on DQ3, and complete the evidence that proves the delivery of each promise made by Vida Mochileira, according to the students' answers (Figure 4).

\section{POINTS OF PARITY} (similar offers)

Travel tips based on their experiences How to plan a trip for free Tips on destinations and low-cost accommodation

Travel itineraries Organization of expeditions Travel content focus on/for women

Business discount for travelers Tips for saving with volunteering work

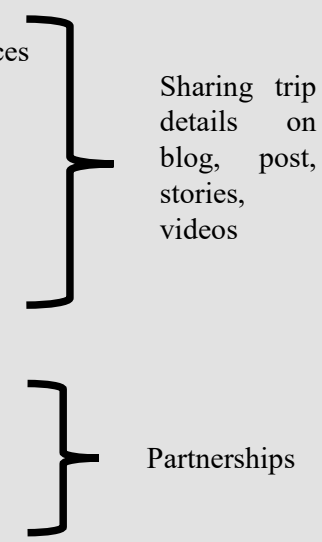

\section{POINTS OF DIFFERENCE} (what is unique)

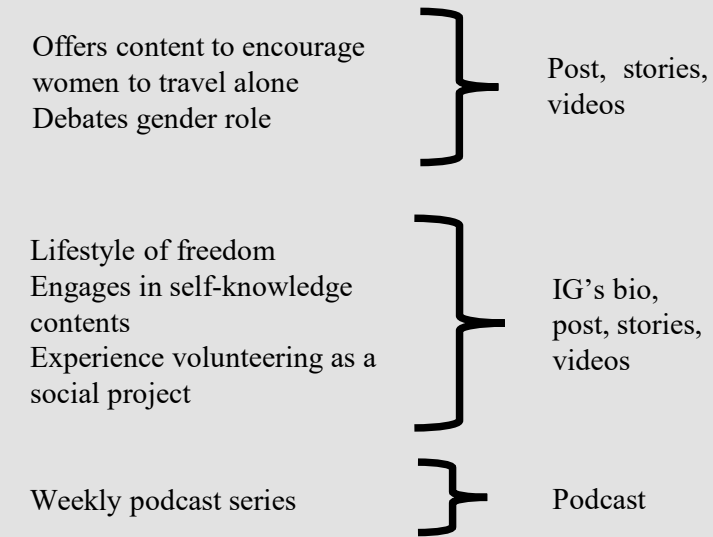

Figure 4. Points of parity and difference. 
Once the evidence is listed, the instructor should highlight to the students that, due to the pandemic context, many of those benefits are either suspended or not feasible, therefore are interrupted by the pandemic. At this point of the discussion, the instructor may consider the following TQ to return to the notes of the opening of the case (Sheet 1) and draw students' attention to what benefits can be delivered by Vida Mochileira to continue relevant to its followers and overcome the period of inactivity enacted by COVID-19 pandemic.

\section{$\mathrm{TQ}$ - What types of VM content are similar to the ones you declared to be more interested in during the lockdown?}

Along with this reflection, it is expected that students will be able to realize that some benefits of Vida Mochileira can be explored in the context of social isolation and travel restrictions and become a strong point of differentiation, for instance: content for women, free lifestyle, self-knowledge, and personal development in a broader way. Thus, the instructor should highlight that these attributes constitute a path to a strategic repositioning of Vida Mochileira during and post-COVID-19. Besides, students may also conclude that a digital business is a lot more agile than a traditional one and can be built 'in real time,' through interactions and exchange of ideas with consumers, adapting to market changes and debating issues relevant to people's lives.

\section{Closing}

According to the plenary discussion and with the students' contributions, the concept of positioning and its main elements were addressed through inductive learning. The classic concept of positioning applied to the context of a digital entrepreneur reveals how an unforeseeable crisis can affect online business, especially when factors related to product offerings are based on traditional decisions similar to those companies operating in physical spaces (offline).

In other words, defining the Vida Mochileira business as a travel blog is as shortsighted as the companies described by Theodore Levitt, in the reputed 1960 article "Marketing Myopia" (Levitt, 1960). At the time of the lockdown caused by the pandemic, Maryana seemed to consider her skyrocketing business threatened by the traveling prohibition. She was cornered by the idea that the content she produced would be of interest for business partnerships if it could recommend the acquisition of travel services.

"Branding is a set of techniques designed to generate cultural relevance and generate meaningful consumer interest online" (Holt, 2016, pp. 41-42). With this statement, the author emphasizes that discussions and interests change according to what impacts people's lives. Being aware of these cultural changes is essential to be relevant on social networks and build a cultural brand. Considering that the case presents a situation of exception triggered by a worldwide pandemic, the instructor may highlight that the brand positioning is a valuable resource to keep track of market changes and allows a brand to adjust its positioning according to the scenario. Pre-pandemic, the blog had an offer mainly related to travel that could not endure a situation of lockdown. The instructor can suggest an exercise to reposition Vida Mochileira during the pandemic, by going through all four items of positioning discussed previously (what, to whom, differential, and evidence) to consolidate the concept learned by the students. He might invite the students to remember that above all, a digital entrepreneur produces content of interest and relevance for people who relate to the ideas it advocates. Hence, Vida Mochileira business is not about traveling or women who travel alone, but how Maryana offers orientation, support, and encouragement to women in their journey of self-knowledge and liberation of limiting beliefs about the feminine. In this sense, Vida Mochileira, without travel, can become a platform for personal development, adding videos, associating with partners from other segments, such as yoga, meditation, astrology, things she has already declared she likes to study, e.g., spirituality, and holistic therapies. It is important to highlight that there is no right answer or a single possibility for positioning Vida Mochileira, and no matter how the brand is positioned, it will face new challenges and opportunities.

The whole discussion about repositioning Vida Mochileira may also cause the students to start thinking about changes in the portfolio and how to disseminate the blog, suggesting new business partnerships with other influencers. The instructor may decide to take note of these ideas separately on the board and refer to them at the end of the session, demonstrating that product portfolio decisions, pricing, hosting platforms, communications strategy, in addition to physical evidence, processes, and people who may integrate the new Vida Mochileira project, configure the 7Ps of services marketing mix (Booms \& Bitner, 1981) and that the understanding of management of these variables will be the subject of a subsequent session. The instructor will thus be able to announce that, by repositioning Vida Mochileira, Maryana Teles changes her entire business and, consequently, she should review the marketing mix and her B2B relationships and establish new competitive advantages over existing or new competitors, identified after its repositioning. 


\section{REFERENCES}

Aaker, D. A., \& Shansby, J. G. (1982). Positioning your product. Business Horizons, 25(3), 56-62. https://doi.org/10.1016/0007-6813(82)90130-6

Booms, B. H., \& Bitner, M. J. (1981), Marketing strategies and organization structures for service firms. In J. H. Donnelly, \& W. R. George (Eds.), Marketing of Services (pp. 47-51). Chicago: American Marketing Association.

Brunner, T. A., \& Wänke, M. (2006) The reduced and enhanced impact of shared features on individual brand evaluations. Journal of Consumer Psychology, 16(2), 101-111. https://doi.org/10.1207/s15327663jcp1602 1

Holt, D. (2016). Branding in the age of social media. Harvard Business Review, $94(3), 40-50$. Retrieved from https://hbr. org/2016/03/branding-in-the-age-of-social-media

\section{Authorship}

\section{Valéria Moreira de Pinho*}

Universidade do Porto, Instituto de Sociologia

Via Panorâmica Edgar Cardoso, s/n, 4150-564, Porto, Portugal

E-mail address: valpinho@hotmail.com

(D) https://orcid.org/0000-0002-3755-2779

\section{Júlia Monteiro}

Universidade Federal do Rio de Janeiro, Instituto COPPEAD de Administração

Rua Pascoal Lemme, no 355, Cidade Universitária, 21941-918, Rio de Janeiro, RJ, Brazil

E-mail address: juliamonteiro@gmail.com

(D) https://orcid.org/0000-0002-5794-5924

\section{Juliana Binhote}

University of Louisville, College of Business, Department of Entrepreneurship

110 W Brandeis Ave, Louisville, Kentucky, 40292, United States

E-mail address: juliana.binhote@louisville.edu

(D) https://orcid.org/0000-0002-9071-7712

* Corresponding Author

\section{Funding}

The authors reported that there is no financial support for the research in this article.

\section{Conflict of Interests}

The authors have stated that there is no conflict of interest.

\section{Plagiarism Check}

The RAC maintains the practice of submitting all documents approved for publication to the plagiarism check, using specific tools, e.g.: iThenticate.
Keller, K. L., Sternthal, B., \& Tybout, A. (2002) Three questions you need to ask about your brand. Harvard Business Review, 80(9), 80-81. Retrieved from https://hbr.org/2002/09/ three-questions-you-need-to-ask-about-your-brand

Kotler, P., \& Keller, K. L. (2016). Marketing management (15th ed.). Edinburgh: Pearson Education.

Levitt, T. (1960). Marketing myopia. London: Boston.

Ries, A., \& Trout, J. (2000). Positioning: The battle for your mind (20th ed.). New York: McGraw-Hill.

Rocha, A., Ferreira, J. B., Silva, J. F. (2012) Administração de marketing: Conceitos, estratégias, aplicaçóes. São Paulo: Editora Atlas.

\section{Authors' Contributions}

$1^{\text {st }}$ author: conceptualization (lead); data curation (lead); formal analysis (equal); funding acquisition (equal); investigation (lead); methodology (equal); project administration (lead); resources (equal); software (equal); supervision (lead); validation (equal); visualization (equal); writing-original draft (equal); writing-review \& editing (equal).

$2^{\text {nd }}$ author: conceptualization (supporting); data curation (supporting); formal analysis (equal); funding acquisition (equal); investigation (supporting); methodology (equal); project administration (supporting); resources (equal); software (equal); supervision (supporting); validation (equal); visualization (equal); writing-original draft (equal); writingreview \& editing (equal).

$3^{\text {rd }}$ author: conceptualization (supporting); data curation (supporting); formal analysis (equal); funding acquisition (equal); investigation (supporting); methodology (equal); project administration (supporting); resources (equal); software (equal); supervision (supporting); validation (equal); visualization (equal); writing-original draft (equal); writingreview \& editing (equal).

\section{Copyrights}

RAC owns the copyright to this content.

\section{Peer Review Method}

This content was evaluated using the double-blind peer review process. The disclosure of the reviewers' information on the first page, as well as the Peer Review Report, is made only after concluding the evaluation process, and with the voluntary consent of the respective reviewers and authors.

\section{Data Availability}

RAC encourages data sharing but, in compliance with ethical principles, it does not demand the disclosure of any means of identifying research subjects, preserving the privacy of research subjects. The practice of open data is to enable the reproducibility of results, and to ensure the unrestricted transparency of the results of the published research, without requiring the identity of research subjects. 


\section{APPENDIX B}

Who did you start to follow during the quarantine?
What are the similarities between Vida Mochileira and other travel profiles? And what is unique to it compared to other travel profiles?

What attracts people to follow Mary? What kind of content does she create?
What types of VM content are similar to the ones you declared to be more interested in during the lockdown?

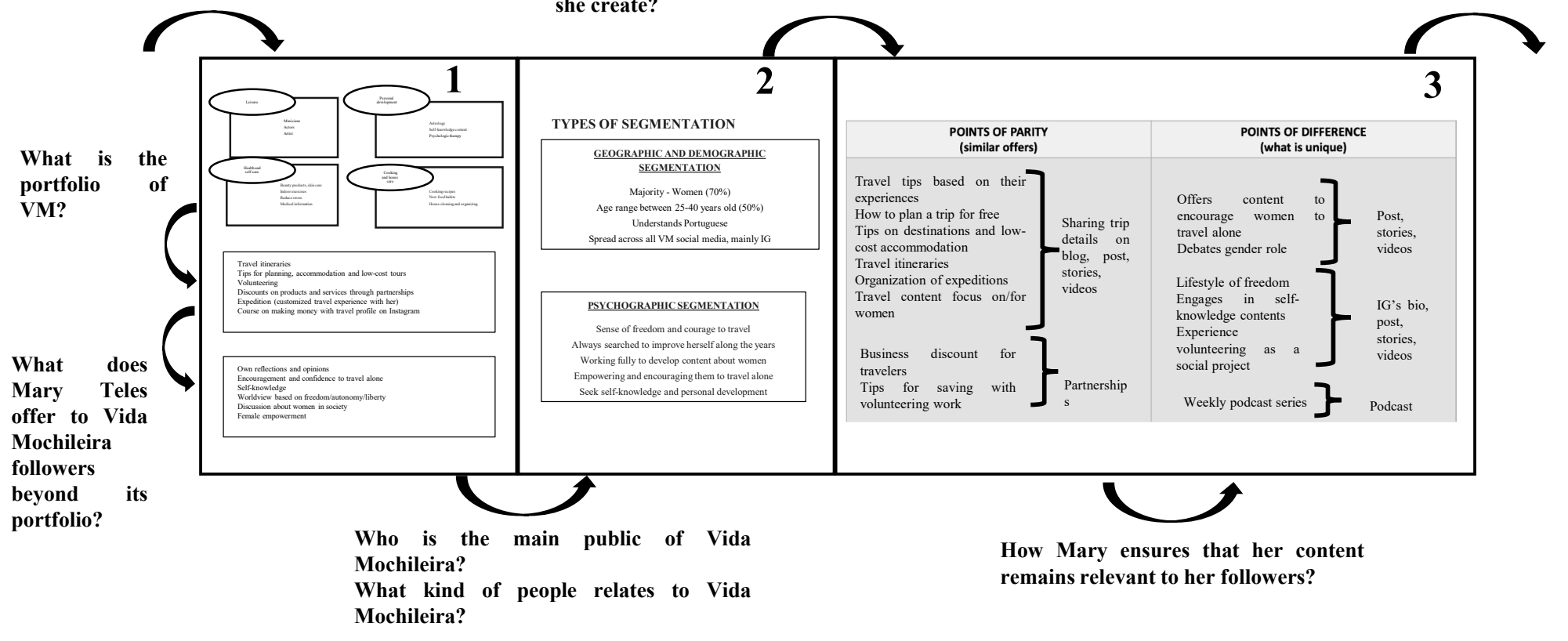

Figure B1. Suggested chart plan schema. 